\title{
The Dislocations and Transgressions in Bhajju Shyam's The London Jungle Book (2004)
}

\author{
Shikha Singh \\ PhD Scholar, Centre for English Studies, School of Language, Literature and Cultural Studies, \\ Jawaharlal Nehru University, shikha52_llg@jnu.ac.in, ORCID: oooo-ooo3-0255-8289
}

\begin{abstract}
The paper explores the multiple transgressions and border-crossings elaborated in the visual travelogue The London Jungle Book (2004), by Bhajju Shyam, a Pardhan-Gond artist and produced by Tara Books, an independent artists' collective specialising in experimental visual literature. The paper discusses the cultural history of "Pardhan-Gond art" and the dislocations and relocations of the art form in the contemporary art world. The paper argues that the personal experience of the artist appears to reflect these shifting categorizations, movements and locations of performance of the art form. The images and metaphors of displacement and transgression have varied connotations in the visual travelogue as they reveal the complex mechanisms of travel and mobility in the contemporary world. The text also articulates the response of the artist to the social, political and economic conditions surrounding the production and circulation of his art, through reimagining his homeland, his cultural ties and his own identity. In a paradoxical sense, the experience of travel and mobility does not symbolise the uprootedness or detachment of the artist, but it brings into effect, with more immediacy, the cultural identity and ties of the artist, as a Pardhan-Gond artist, in the contemporary art world. Furthermore, the materiality of the crossover text challenges the notions of media, genre and readership, associated with the picturebook format, destabilising the categories and assumptions associated with the literary genre.
\end{abstract}

Keywords: Pardhan-Gond art, Bhajju Shyam, Tara Books, tribal art, book illustration.

\section{Introduction}

The London Jungle Book (2004) by Bhajju Shyam is a visual travelogue that narrates the experience of the artist during his two-months long stay in London. Shyam and fellow artist Ram Singh Urveti were commissioned by a restauranteur to paint murals on the walls of a swanky eatery at Islington in London, in 2002. Shyam narrated his experience of the metropolis to the editors at Tara Books, during a workshop. The amusing observations matched with the insights that accompanied those observations of the artist instantly appealed to the Tara Books team. This led to a proposal for a book project - a collaboration between the artist and Tara Books (Wolf \& Rao, 2004, para. 4). Shyam provided the illustrations for the visual travelogue, while the editors at Tara Books recorded and translated his narrative and provided brief commentaries in English for the art. Tara Books is an artists' collective and publisher of graphic books, based in Chennai, that specializes in collaborative and innovative works with folk and tribal artists. Bhajju Shyam belongs to the Pardhan-Gond school

(c) AesthetixMS 2021. This Open Access article is published under a Creative Commons Attribution Non-Commercial 4.0 International License (http://creativecommons.org/licenses/by-nc/4.o/), which permits non-commercial re-use, distribution, and reproduction in any medium, provided the original work is properly cited. For citation use the DOI. For commercial re-use, please contact editor@rupkatha.com. 
of painting. The art tradition originated within the premise of the Museum of Mankind in Bhopal in the late 1980's when Jangarh Singh Shyam, a young Pardhan-Gond from the village of Patangarh in Mandla district arrived at the museum, and took up the brush under the patronage of the artist and critic J. Swaminathan, the latter who was also the Director of the museum. Other members of the community followed on his footsteps, and introduced their own distinctive styles, techniques and interpretations of the art form. Pardhan-Gond artists have, since then, been involved in a number of collaborative-projects and commissioned works, some of which involving new media such as animation, book illustration and digital media (Chatterji, 2012a, Douglas 2014). At present, Pardhan-Gond art has evolved into a highly sophisticated art form encompassing wide range of subjects, themes, forms of representations and techniques.

The book was published in association with the Museum of London. Since, the visual travelogue explored the city and its culture from the perspective of an adivasi artist from India, it was fitting that the museum served the role of a patron for the project. Following the release of the book, the art done by Shyam was displayed at the foyer of the Museum of London for nearly three months, between 2004-05 (Museum of London - Annual Report-2004/05, p. 23). The book was a success among international readers, with Tara Books being able to sell the rights for publication to publishers in different languages, in different countries (Catalogue 2018-19, 2018, p. 118). The popularity of The London Jungle Book as well as the first picturebook published by Tara Books in collaboration with folk and tribal artists - Beasts of India (2003), to which Shyam was also a contributor, laid the foundation for a long partnership between the artist and the publisher. Some of the books to have come out from the fold, include The Night Life of Trees (with Ram Singh Urveti and Durga Bai), published in 2006 and That's How I See Things (with text from Sirish Rao), published in 2007. The former won the Bologna Ragazzi Award in 2008 and the latter accorded him an IBBY-Certificate of Honour for Illustration in 2010. In 2016, Shyam had his first solo exhibition at Ojas Art, a private gallery in Delhi. He also received one of the highest state civilian awards, the Padma Shri in 2018.

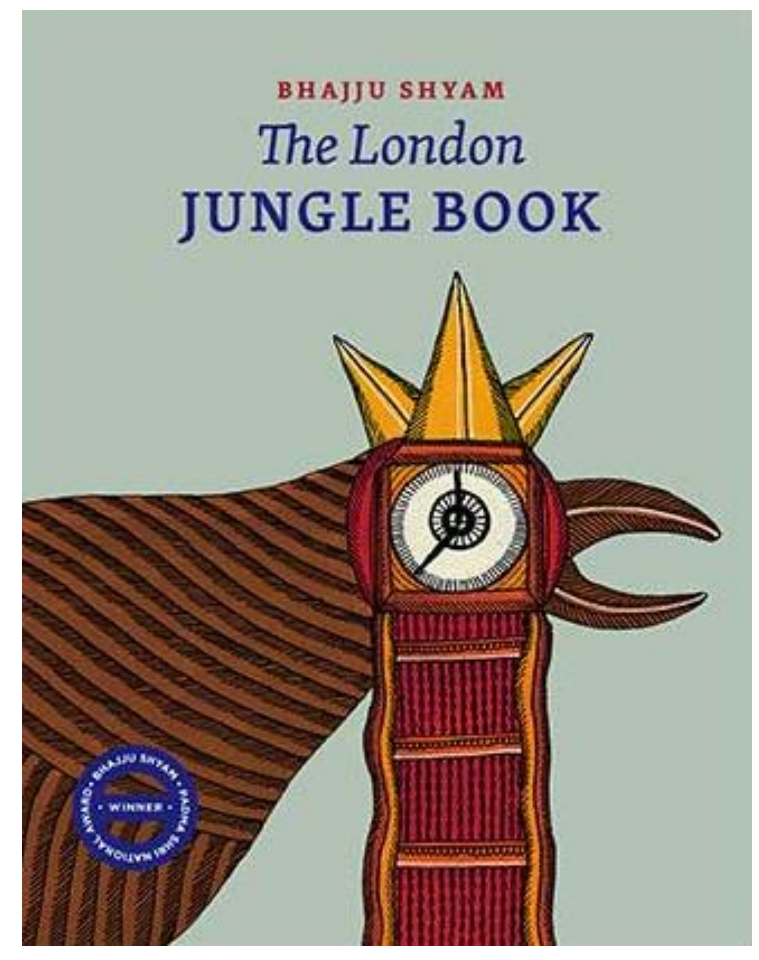


Figure 1: The cover page. Art from the book titled The London Jungle Book by Bhajju Shyam Copyright 2004 Tara Books Pvt Ltd, Chennai, India. tarabooks.com

The London Jungle Book, published in his early years as an artist and illustrator, and which catapulted him into wide international recognition, can be considered one of the most significant works of the artist. The title of the book refers to Rudyard Kipling's The Jungle Book (1894) whose romantic fable about a boy raised by a pack of wolves in the deep forests of the Central Provinces (presently states of Madhya Pradesh and Chhattisgarh in India) have delighted children for a long time. Kipling's The Jungle Book always brings to memory the exotic flora and fauna of the Indian forests as depicted in the book - the image immortalized in the many Disney adaptations of the book. Shyam's visual travelogue displaces the trope of the exotic and savage landscape from the former-colony to the very heart of the former-imperial order, within the city of London. Further, as suggested in the epilogue to the book, by Gita Wolf and Sirish Rao (2004, para. 4), the narrative also recalls Verrier Elwin, the anthropologist, writer and social worker from England who settled among the Gonds, married twice within the Gond community and spent some more than twenty years with them. His ethnographic writings have been criticised for creating a romantic and idealistic notion of the tribal communities in India, even as they were accompanied with valuable insights and marked by a sympathetic understanding of their culture (Guha, 1996, p. 328). We are also reminded of the artist's mentor Jangarh Singh Shyam, the first Pardhan-Gond artist to have gained wide reputation in the art world, and who single-handedly gave birth to an entire school of painting. Jangarh Singh Shyam's works were displayed in museums and galleries in the west, most notably at the Magiciens de la Terre exhibition at Centre Pompidou in Paris, in 1989. His guidance, support and encouragement paved the way for others in the community to start painting. The artist's tragic death at the Mithila Museum at Niigata in Japan in 2001 however raised questions regarding the transnational networks of production of adivasi art, the discourses that surround the art practice and precarious situation of the artists (Dutta, 2018; Luis, 2019). The various crossings, dislocations and displacements experienced by these figures in history - whether it is the colonial fabulist, writer and poet, Kipling; or the indigenized anthropologist from England, Elwin; or the young and talented adivasi artist, Jangarh Singh Shyam - at the throes of the global flows and exchanges appear to resonate with the experiences of the artist, Bhajju Shyam. The metaphor of travel and displacement reconfigure in the works of these historical figures. Further, intercultural encounters and exchanges deeply influenced their art and writing. Though the book does not directly allude to these historical figures, the visual travelogue does seem to bring to context the range of historical conditions under which travel is made possible and the diverse figurations of the traveling artist in the past and present. Furthermore, the narrative brings to fore the regional history of the village of Patangarh, in the Mandla district of the state of Madhya Pradesh, and how the place has inspired and figured in numerous historical and cultural discourses and in turn, has also gained prominence as a cultural hotspot, after the emergence of Pardhan-Gond art.

Bhajju Shyam started his career as a nightwatchman in the city of Bhopal. He began working under the tutelage of Jangarh Singh Shyam, till his works gained widespread acclaim and recognition, and he was able to chart off his own career as a Pardhan-Gond artist in the 199os. The turning point of his career, was his collaboration with Tara Books for printed graphic narratives. He emerged as a leading illustrator and storyteller for children and adult graphic narratives, owing to the versatility of his style and technique, ability to adapt to different genres and media as well as the facility with which he could engage with a wide spectrum of readers. Displacement and migration have varied connotations in the life of the artist. Afterall, his career as an artist would not have been possible had he not migrated to the nearby city of Bhopal from his village in Patangarh. Similarly, the Gond-Pardhan art would not have seen the light of the day, had it not 
been for the young Jangarh Singh Shyam's decision to take up the opportunity offered by Swaminathan at the Museum of Mankind. The wide international exposure, accessibility to the urban markets and opportunities in the form of commissioned works as in the case of Bhajju Shyam's trip to London have played a big role in establishing the Pardhan-Gond art in the contemporary art world. As Roma Chatterji, remarked "The city is not only the subject that many folk artists draw upon to stress the contemporaneity of their art, but it is also the site of novelty and experimentation" (2012b, para. 1). The perceived categories of "modern" and "pre-modern," that are often brought to use in the case of non-elite artists, especially belonging to folk traditions or indigenous groups, have inspired many artists to insist on their "contemporaneity" or coeval existence through juxtaposition of images and scenes in their art that signify "the modern" modern infrastructure and modes of communication, urban landscapes and current lifestyle of people living in towns and cities. The art further targets urban consumers with disposable income and taste for folk, tribal and popular arts. And, while, displacement might appear as a boon in disguise, there is also a downside to it which cannot be easily forgotten. The changing socio-cultural conditions have resulted in unfavourable situation forcing many indigenous communities to discard their land and traditional practices, often without any hopes of resettlement and at the expense of facing cultural annihilation. The demand for separate state and political autonomy has been a direct outcome of the neglect and apathy faced by the indigenous communities, especially those inhabiting the central states of India, to reclaim their "homeland" (Prasad, 2015, pp. 40-41). Thus, the tropes and metaphors of displacement and migration in the works of Shyam, helps to understand how notions of place, identity and agency are articulated in his work, and as a result how the political is conceptualised in the works of the artist.

The notion of border crossing, dislocation and transgression evoke different meanings and interpretations, at various registers within the graphic narrative. The book does not essentialize the experience of migration, dislocation and boundary crossing, though it certainly attempts to look at the experience of travel, movement and displacement shared by others in the present as well as in the past times. The narrative explores the different conditions under which people travel and the differences in their experience of travelling. Globalization has accelerated the mobilization of bodies, goods, information and media, but it has also created vast disparities in how mobility of an individual is reconfigured. The effects of colonialism, the two world wars and capitalism, in the modern times uprooted the lives of many individuals and communities, at the same time, they brought about new institutions, technologies and practices to control the movement of goods, bodies and information (Clifford, 1997, p. 7). It has posed new questions regarding the materiality of travel - the location, modern subject of travel and the corporeal experience of travel (Kaplan, 2003, p. 209). The border-crossing of the Pardhan-Gond artist not just in terms of the space and location, but also in terms of the artistic practice, choice of media, subject matter and lastly in representation of the self provides a fertile ground for investigating how the belongingness, agency and identity of the artist is explored and transformed in the narrative. This transformation takes place on several accounts: the mode and medium of narration, the genre and form of the graphic narrative, the visualization of the city of London, the visualization and narrativization of the self and finally the transformation and experimentation within the art tradition itself.

In the following paper, I ruminate on the multiple transgressions and border-crossings elaborated in Bhajju Shyam's visual narrative. I shall explore the cultural history of Pardhan-Gond art and the dislocations and relocations of the art form in the contemporary art world. I argue that the personal experience of the artist appears to reflect these shifting categorizations, movements and locations of performance of the art form. These transgressions and displacements reveal the arbitrariness and porosity of cultural identities and land boundaries. Yet, they also reveal something 
important regarding the response of the artist in recreating his homeland, his cultural ties and his own identity through his art. It highlights the paradoxical situation of Shyam's movements, where "being grounded is not necessarily about being fixed; being mobile is not necessarily being detached" (Ahmed et al., 2003, p. 1). In a paradoxical sense, the experience of travel and mobility does not symbolise the uprootedness or detachment of the artist, but it brings into effect with more immediacy the cultural identity and ties of the artist, as a Pardhan-Gond artist, in the contemporary art world.

\section{The Dislocations within the Production and Reception of the Art}

The London Jungle Book is a multimodal narrative which makes use of text and images to narrate the experience of the artist in London. While, the picturebook format of the book hints at a young readership, the complexity of the subject matter suggests a mature target audience. In fact, the transgressions and boundary crossings are not limited to the form and content of the narrative but extends to the artistic practice of the artist himself. The Pardhan-Gond art tradition in itself is in a moment of transition with the opportunity for new modes of production and circulation, new platforms for performance and new opportunities for experimentation and innovation in the art form (Chatterji, 2012a). The re-evaluation and reception of the works of Bhajju Shyam are also subjected to the changes in the frameworks and criteria for approaching adivasi art. These movements and re-interpretations offered for adivasi art in the context of transnational production and reception of art, provides an opportunity to critique the very material conditions and institutional discourses that limit the movement and interpretation of adivasi art as fixed in time, ritualistic, repetitive, community-oriented and ethnographic in nature.

The Pardhan or Pardhan-Gond is a sub-clan of storytellers, musicians and genealogists within the Gond community, dependent on the latter for their living and subsistence (Knight, 20oo, p. 109). The Gonds are one of the largest indigenous tribes in India. The decline of the Gonds during colonisation, and the subsequent loss of land and access to resources post-independence meant that the Pardhans could no longer rely on the Gond patronage. The Pardhans of the Mandla district have been extensively documented by Shamrao Hivale, a social worker and a notable scholar, in The Pardhans of the Upper Narbada Valley (1956). It was apparently in the Mandla district in Central India, that Verrier Elwin, the eminent anthropologist, and the later draughtsman of independent India's Tribal policy, along with Hivale, his companion - spent twenty-two years working for the people, while also documenting their life and culture. Elwin lived in Patangarh among the PardhanGonds - "the gay, romantic minstrels of the Gonds" (1964, p. 120), from 1940 till 1954. His second wife Lila was from Patangarh, who is also supposedly related to Jangarh. He fondly wrote about the Pardhan women, who came to paint murals in his newly-built house at Patangarh, recalling their "sensitivity" and "temperamental" nature since they "had no tradition of doing anything for show or for pay" (1964, p. 123). He (1964) wrote:

"This Gond art is characterized by symbolism and by a very simplified method of representation: a bird may be shown by its wings, a dance by his legs. And the Gonds seem to have little idea of symmetry or straight lines. When I raised this point with one of them, she replied, 'But trees in the forest do not stand up straight, nor do the branches extend equally on either side. The pattern on the wall is like the forest.' And so in many cases it was, and the effect was not unpleasing." (p. 123)

Elwin was among one of the few, if not the first to use the term "art" in relation to the tribal communities, as is evident from the title of his book, The Tribal Art of Middle India (1951). While, none can deny the links the contemporary Pardhan-Gond artists have with that of the early tradition of storytelling, musical performances and paintings; scholars like Udayan Vajpeyi explain 
"Gond paintings" to be of recent origin. He traces its origin to experiments with folk and tribal arts under the supervision of Jagdish Swmainthan, the eminent art critic and artist who was the influential figure behind the institution Bharat Bhavan or Museum of Mankind in Bhopal, for promoting tribal arts and culture and supporting and encouraging tribal artists (Vajpeyi, 2010, section 6). It was in the 1980 os that attempts were made to introduce tribal artists to new media and expose them to other art practices, after which they shifted to working with acrylic colours on paper from painting on walls using natural pigments. Vajpeyi maintains that the art tradition should be referred as "Jangarh Kalam," since Jangarh Singh Shyam was one of the first Gond artists to receive international acclaim, and it was under his influence that other artists took up painting and like him, the more promising among them began experimenting with different themes, styles and techniques (2010, section 9). Since then, changes in social, economic, political and cultural conditions have influenced the Gond artists to re-imagine the forms of their artwork, the preferred media and distribution channels; and invest in discourses surrounding their work by providing their own interpretation and commentaries.

Jyotindra Jain (2018), the famous scholar and critic on folk and popular arts in India, also share the sentiments. In fact, he insists that the kind of art work performed by Jangarh Singh Shyam was highly individualistic and had no precedent in collective tradition, and some of the best artists to come out from the school of painting, who had initially worked as his assistant have developed their own style and vocabulary to be regarded as individual artists rather than belonging to a particular group or school of painting (Jain, 2018, p. 16). Perhaps, what truly brings them together are not the similarities to be found in their own work, but the similarities in how their art has been received and interpreted in the art world. Notwithstanding the recent interventions in the field of exhibition, art history and cultural practices, certain prejudices and conventions are hard to counter when it comes to the conceptualization and reception of folk and tribal artists (Das, 2010, pp. 12021). Ethnographic frameworks applied to Pardhan-Gond art neglect the wide diversity in the art style and technique of the artists who are labelled as Pardhan-Gond artists. On the other hand, a purely aesthetic criteria that disregards the art from its cultural-material conditions of production can only provide a partial glimpse of the contemporary art world. Annapurna Garimella has argued that the decisions made by the artist from the choice of the materials, to the style of representation, to the production process can have diverse consequences, which in turn can have great 'political repercussions for the artist's sense of self and practice' (Garimella, 2010, p. vii). Thus, the form and the materiality of the work cannot be isolated from what is political in the art. And rather than, attempting to situate the work by Bhajju Shyam within preconceived categories of "adivasi art" or "Pardhan-Gond art" or "Jangarh Kalam" or even "contemporary art;" it makes more sense to understand the choices and decisions made by the artist - not just in terms of the themes and subject of representation but also in terms of the mode of representation, the media and the style of representation - and what it can reveal to us about our own contemporary times.

Shyam is aware of these challenges in the reception, interpretation and perception of his work. Gita Wolf and Sirish Rao (2004) noted Shyam's response when the latter was questioned about the unconventional theme and stylistic innovations in the book:

“. . . how come they [other artists] have the right to paint anything they like, but I must stick to wild animals because I'm a tribal? Times have changed, I live in a city now, and I have been on a plane to London. That's not to say that I will throw my tradition away. I can't it's in me. The new is done with the old in my blood. So even the pictures I draw of London-they will have a Gond twist, be a Gond View of London. Though we are united, and we speak with one voice, not all tribals are the same." (para. 11) 
Wolf and Rao (2004) comment that the assumption that all artists from the tribal community work in the same paradigm and choose from within a set stock of subjects is a result of the tendency to "essentialise the Gond imagination as the romantic other of our modern consciousness" (para. 8). Rashmi Verma (2002) has criticized the different representation of "the adivasi" in contemporary discourse - the figure of the "backward" adivasi in colonial narratives or the figure of threat or an unsuspecting victim of global capitalism in postcolonial reconfigurations (pp. 216-233). She (2013) considers the figure of "the adivasi" as an amalgamation of contradictory discourses that articulate the irony of Indian modernity (p. 750). The figure of "the adivasi" is the literal re-incarnation of the national cultural heritage and therefore the traditional arts and practices of the community are subjected to state protection. On the other hand, the adivasi must aid in the progress and development of the nation state by making way for urbanization, development and extraction of resources by being subjected to forced displacement and migration. In her readings of Pardhan-Gond art, Verma argues that "the art itself offers an allegory, however partial and incomplete, of the process by which it enters the world and is both transformed by it and transforms it" (2013, p. 749). Thus, the processes of singularization, commoditization and reification of the Pardhan-Gond art in the global market exposes the arbitrary decisions through which adivasi art is either excluded or selectively appropriated in art history. The movement of the Shyam's art from the confines of the tribal and ethnographic art gallery to the walls of a high-end restaurant in London to the pages of a visual travelogue to being part of a travelling exhibition depicting the work of an adivasi artist to finally emerging on its own right as a work of a "contemporary" artist at the New Delhi based Ojas Art Gallery, in 2016 bespeaks the movements, dislocations and transformations of Shyam's art.

\section{The London Jungle Book as a "Crossover" Graphic Narrative}

Tara Books, as noted in their Catalogue 2018-19, is "a collective of writers, artists and designers" based in Chennai that "publish illustrated books for children and adults" across a wide range of genres such as "children's literature, social and art pedagogy, popular culture, photography and art" (2018, p. 2). The publishing collective has emerged as an influential agent in promoting and publicising the works of non-elite artists and providing them opportunities to work in unconventional projects along with other professionals from the fields of art, graphic design, storytelling and performance. They are widely recognized for their picturebooks for both children and adults, based on folk and tribal art. The collective also produces limited edition, handmade books using silk-screen print techniques which can be effectively regarded as objects of art. In their catalogue they mentioned that they "value experimentation: in content, design and production," especially by exploring the physical aspect of the book (2018, p. 2). They have also insisted that their "engagement with the rich diversity of Indian folk and tribal art" by presenting them in the book form and "combining them with contemporary design and production" has "changed the perception from which stories are usually told" (2018, p. 2). Rathna Ramanathan (2014), an independent graphic designer who has worked with Tara Books on numerous occasions including The London Jungle Book, noted that " $\mathrm{t}]$ he publishing process at Tara is an iterative journey where the idea for a book can originate from numerous contexts: from the traditional starting point of a text by an author to a conversation with an indigenous artist or the subject interests of a designer" (p. 126). A glimpse at the range of titles reveals different approaches used for different art forms and artists. While, some books curate the work of the artists under one common theme; in others, the basic way that artists work is retained but it is provided with a new context or approach; and in some others through a collaboration between the artist, illustrator and designer new composite artworks are created (Chadwick-Dobson, 2011). 
Gita Wolf (1997) notes, that "a conscious hybridisation of traditions, a translation of traditional visual idioms into a modern situation" (p. 23) is important not just for encouraging and preserving the indigenous visual cultures but also to counteract the glut of mainstream conventional modes of illustration. Adaptation of an art form to new media must be done carefully. It involves "intellectualising them removing them from their own specific social and cultural mores" which could result in "unexpected, authentic, and truly alternative narratives," notes Gita Wolf (1997, pp. 23-24). Wolf is conscious of how the different frameworks and modes of display can alter the signification and value of a work of art. Appropriation, mediation, translation and hybridization involve both collaboration and negotiation. The collaboration should be meaningful for the artist and the terms of collaboration should respect the individual style and vision of the artist. It is important that the publisher is informed of the personal and collective significance of the art form, as they conceive of a project for adaptation of traditional forms of art. The process of adaptation and hybridisation also puts the responsibility on the publishers and the artists to articulate and develop their own theorizations of the transformation.

The London Jungle Book makes use of the picturebook format in its use of "slimmer pagination," "lesser narrative breadth" and lack of "partitioning of space" to create an immersive media for the reader (Groensteen, 2013, p. 52, 53). The "materiality of the book, the sensuality of color, and the sustained encounter with aestheticized worlds" that the picturebook offers allows the reader "a different experience, in which intertwinings (sic) of color and imagined worlds are more considered, more coordinated, and more self-contained, producing something more absorbing, even contemplative, for their readers" (Bukatman, 2016, pp. 89-90). The unhurried pace of the narrative, absorptive media and the entry into the "aestheticized worlds" of the artist's creations provide the ideal conditions for both young and adult readers to acquaint themselves with the artworld of Shyam. The London Jungle Book by bridging the gap between fine art and commercial art explores the subversive potential of the picturebook format. Children of young age and teenagers are known to respond well to abstract art (Wolf, 1997, 17). The multimodal nature of the narrative due to the presence of text and images further enable multiple entry points into the text. The manipulation of the reading paths and the graphic design of the book further amplify the arguments and dialogues presented in the book (Ramanathan, 2014, p. 138), so that the reader is forced to pay attention to the nuances of the interaction and exchange between the words and images. Ramanathan considers the book to be "a conceptual gallery space" for the artist (2014, p. 139). The sequence of arrangement of the pictures and the text, the page layout and the book design play an important role in the book, in manipulating the experience of the reader in viewing and interpretation of the art.

The sequence of arrangement of the pictures and the text, the page layout and the book design play an important role in the book. To elucidate the point made by Ramanathan, the first painting, in the book is called "Leaving My World Behind" and it depicts a large face on the doublepage spread, as half jubilant and half sad, and attached to different images such the image of a mouth with "language" written on it in Hindi, a house, an elderly couple, a transistor, a porcupine, a plough, a child, a cow, a tree, a rooster, a cot, a bullock cart and a mango. The painting is preceded by a short narrative of the events that lead to the departure of Shyam - his securing work in London and the admixture of "pleasure and pain" on leaving home and travelling to a new place. There is an enlarged picture of the face with the "50-50 expression" on the verso page, facing the narrative. Thus, the book opens with a detail of the art in the following page. This image provides the reader the opportunity to observe the details of the art. One can note the intricate patterning used for spatial differentiation. The magnification makes visible the thick uneven lines of the brush; the spill of the colour that does not match the lines of the figure, the lack of uniformity in the patterns and 
designs that fill up the space-these elements signify the presence of the "authorial illustrator" (Ramanathan, 2014, p. 130) behind the conceptualization and focalization of the image. The large size format of the book, the vivid pictures, rich colours, sparseness of the text, as well as the strategic manner in which the text frame the pictures indicate the publisher's intention to let the pictures communicate to the readers without any hindrance. Thus, the discursive, the material and the visual components signify a strong sense of authorship.

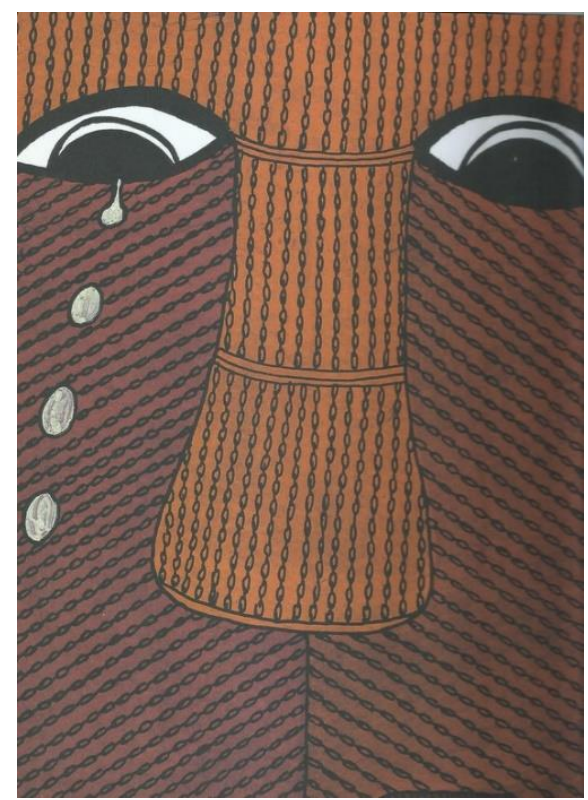

Figure 2: Detail from “Leaving My World Behind.” Art from the book titled The London Jungle Book by Bhajju Shyam

Copyright 2004 @ Tara Books Pvt Ltd, Chennai, India. tarabooks.com 


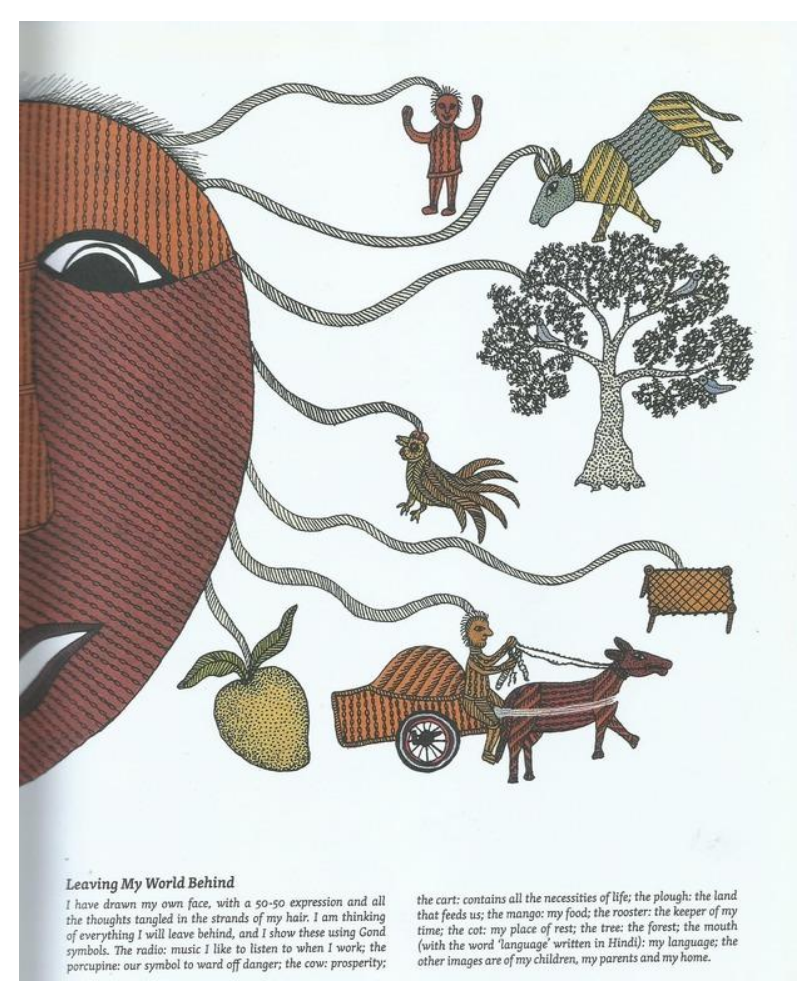

Figure 3: Leaving My World Behind. Art from the book titled The London Jungle Book by Bhajju Shyam Copyright 2004 Tara Books Pvt Ltd, Chennai, India. tarabooks.com

Lastly, the crossover picturebook transcends market genres and categorizations. I invoke the term, "crossover" as outlined by Christophe Dony (2012) in his analysis of graphic narratives by the Australian artist and storyteller, Shaun Tan. He describes a crossover fiction as "a malleable form that moves between worlds and (literary) genres alike and which, to varying degrees, 'engage[s] with spatio-temporal fragmentation, dis/connection, and dis/continuity' in order to transgress aesthetic, cultural, and generic norms, including the linearity of history, the traditions of colonial travel writing, and the dichotomizing of comics as image/text" (Domy, 2012, p. 85). He mobilizes the concept of "crossover" from thematic and generic frameworks to reflect the "inbetweenness" of the migrant as well as the decentralization of the fixed cultural and national identity of the dislocated individual (Domy, 2012, p. 85). Thus, the adaption, hybridization and translation of the artwork by Bhajju Shyam provides another instance of displacement and dislocation in the production, distribution and reception of the graphic narrative. The need to articulate his own personal experiences and create his own visual idiom required the artist to move beyond the traditional themes, styles and modes of representations, experiment with the new media, create new interpretative frameworks for the reception of his art work as well as rework his own connection with the inherited tradition and community.

\section{Notes on the Travels of an Artist}

The notion of "travel" in the narrative takes a different turn: as an inversion of the narrative of discovery and colonial ethnography. Wolf and Rao (2004) write how the visual narrative manages to "reverse the anthropological gaze" on the city of London (para. 16). They further provide a sketch of the author as a traveler as "a humble and open voyager, willing to show his vulnerability" (Wolf \& Rao, 2004, para. 19). The visual narrative continuously underscores the conditions under which the journey was made possible and how Shyam's mobility is a result of a paradoxical situation where artists like him must travel for work. Shyam is not the autonomous, free and mobile figure of 
contemporary travel narratives. On the contrary he is a part of the itinerant labor force that constitutes the mass of the global flows in the neoliberal world order. We are constantly reminded of this fact, on various occasions in the visual narrative, such as the picture which shows him painting a human figure with a trident in one hand and a bird in another, atop a fish floating in a bowl, where the text reads "Here I am doing what I do for a living" (Shyam, 2004, "Working for the Stomach"). The human figure depicted by him is "Shankar Bhagwan," (Lord Shankar) the Hindu deity worshipped by Gonds. The picture represents the nature of his work at the restaurant, and his source of income. In another picture, he represents the airport as an eagle depicted inside a circular frame with its wings spread wide swallowing termites (Shyam, 2004, "Airport"). Beneath the picture the text explains, the airport with its intimidating security protocols and verification procedures appeared to him as a giant bird of prey swallowing human beings like termites. The picture is on the other hand supposed to resemble the impression made by an office stamp, without which one cannot travel.

In another section of the book, the text reads, "The main difference is this: anyone who has work in London is alright. But in India, you can work all day and still be poor" (Shyam, 2004, "Work"). Shyam's narrative then makes use of the genre of travel writing to present the different conditions of mobility under the neoliberal conditions. The ideal state of mobility based on the idea of freedom to move is a privileged concept. Others move in pre-charted paths and through select nodes, in search of livelihood, though not completely out of their free will. Shyam's narrative is not an account of forced displacement but an instance of an artist from a marginal community being co-opted in the capital order of cultural production. The visual travelogue containing artworks done by Shyam, accompanied with the verbal commentaries ascribed to the artist in the form of a commercial print genre for a global audience signifies the moment of transformation of an art form. On the other hand, the commoditization and dissemination of the art form has also made the art world take note of it. In another section of the book, Shyam ruminates on his inability to converse with the people who came to see him work. In another section of the book, titled "Art is the Only Language I Have," the text reads:

"If only I had language! There was no way I could explain my thoughts and my art to them. When something means the world to you, and absolutely nothing to someone else, that is the gap that only language can fill." (Shyam, 2004)

The inability to communicate due to the lack of a common language is acutely felt in the passage. Art in his case becomes an alternate system of communication, perhaps, not as useful as language in social circumstances, but equally, if not more impressive and influential. In his discussion of Ganga Devi's “American Series” paintings, Jyotindra Jain explains how the Madhubani artist "mythologised the "reality" by transfiguring the mundane objects of daily American life such as cars, flags, phone booths, roller coasters, people in malls, and such others into "completely imaginary and 'fantastic' objects" by stripping them off of their familiar context and formal representations (2005, p. 509). Jain considers these paintings as the moment of re-awakening of artistic consciousness of the painter, where she is able to envision a parallel reality in an adapted visual idiom. Thus, the projection of Gond myth on London cityscape is much more than an example of reverse appropriation of the cultural icons of London by a Gond artist.

In the last section of the book, Shyam paints himself as the "Bhujrukh," or the traditional storyteller in the Gond community (Shyam, 2004, "The Bard of Travel"). While, the traditional storytellers narrated community songs and myth, Shyam has created a reversal of sorts. He narrates his experiences of travel and art, and he narrates to his community as well as to the book's readers. Thus, the final section of the book represents the artist and the storyteller at the cusp of re- 
envisioning his own identity and agency as an artist. The crossing over not only helped him reimagine his own artistic idiom and visualize his agency as an artist-thinker but also helped him reach-out to others challenging the boundaries between the self and the other. The synergistic metaphors in his art recalls the hybridity and alterity in the construction of the self. The traveling self by exposing the self to the strangeness of the new place is forced to confront the alterity or otherness within the self.

\section{Conclusion}

The present paper takes the border crossings and transgressions of Bhajju Shyam's graphic narrative The London Jungle Book as the starting point for queries into the nature of movement, dislocation, displacement, migration and travel under the contemporary conditions of global flows. The paper argued that the graphic narrative highlights the potential of the border crossings and transgressions by not only questioning the received boundaries and cultural differences but also envisioning a space and mode of interaction that permeates through the conceived boundaries and cultural differences. The crossover text of the Shyam in fact, enables a critique of the arbitrary categories of contemporary art production and reveals the biases and prejudices that lay behind such assumptions, especially in context of Shyam's art. Furthermore, the graphic narrative in refusing to provide a closure, provides a space for existence of contesting arguments and dialogues where the multiple meanings can co-exist. The paper finally, reiterates the importance of taking into consideration the nuances of articulation, presentation and representation in crossover picturebooks, to understand the cultural politics of meaning making and identity formation.

\section{Funding Disclosure/Acknowledgement}

The author did not receive any funding or had any competing interest in the publication of the research. The author would like to thank the Tara Books Team for the permission to use the images in the article.

\section{References}

Ahmed, S., et al. (2003). Uprootings/regroupings: Questions of home and migration. Berg.

Bukatman, S. (2016). Hellboy's world: Comics and monsters on the margins. University of California Press.

Tara Books. (2018, September 18). Catalogue 2018-19: UK \& Europe. Issuu. https://issuu.com/bouncesalesandmarketing/docs/tara_books_2018_2019_catalogue_uk

Chatterji, R. (2012a, August 4). Dotting the paper, the town. Indian Express. http://archive.indianexpress.com/news/dotting-the-paper-the-town/983532/o

Chatterji, R. (2012b). Speaking with pictures: Folk art and the narrative tradition in India. Routledge.

Clifford, J. (1997). Routes: Travel and translation in the late twentieth century. Harvard University Press.

Das, A. (2010). Metropolitan and traditional: An exploration of the semantics in contemporary Indian arts discourse. Etnofoor, 22(1), 118-135.

Chadwick-Dobson, M. (2011, November 12). Approaches to publishing: Tara. The Damroo Project. IDC, IIT Bombay. http://www.damroo.in/meagan.pdf

Dony, C. (2012). Towards a vocabulary of displacement and utopian possibilities: Reading Shaun Tan's The Arrival as a crossover text. Studies in Comics, 3(1), 83-105. https://doi.org/10.1386/stic.3.1.83_1

Douglas, T. (2014). Pardhan Gond adoption of new media. The South Asianist, 3(1), 18-27. http://www.southasianist.ed.ac.uk/article/view/162 
Dutta, A. (2018). Invisible webs: An art historical inquiry into the life and death of Jangarh Singh Shyam. Indian Institute of Advanced Studies.

Elwin, V. (1951). The tribal art of middle India: A personal record. OUP.

Elwin, V. (1964). The tribal world of Verrier Elwin. OUP.

Garimella, A. (2010). The education of a curator. In A. Garimella (Ed.), Vernacular in the contemporary: Part 2 (pp. iv-x). Devi Art Foundation.

Garimella, A. (Ed.). (2010). Vernacular in the contemporary: Part 2. Devi Art Foundation.

Groensteen, T. (2013). Comics and narration (A. Miller, Trans.). University Press of Mississippi.

Guha, R. (1996). Savaging the civilised: Verrier Elwin and the tribal question in late colonial India. Economic and Political Weekly, 31(35/37), 2375-2389.

Hivale, S. (1946). The Pardhans of the upper Narbada valley. OUP.

Jain, J. (1997). Ganga Devi: Tradition and expression in Mithila painting. Mapin Publishing and the Mithila Museum.

Jain, J. (2005). Women artists of rural India. In B. Ray (Ed.), Women of India: Colonial and postcolonial periods (501-523). PHISPC.

Jain, J. (2018). Jangarh Singh Shyam: A conjuror's archive. Museum of Art \& Photography (MAP).

Kaplan, C. Transporting the global subject: Technologies of mobility and location in an era of globalization. In S. Ahmed et al (Eds.), Uprootings/regroundings: Questions of home and migration (207-224). Berg.

Kipling, R. (1894). The Jungle Book. Macmillan.

Knight, R. (2000). The 'bana', epic fiddle of central India. Asian Music, 32(1), 101-140. https://doi.org/10.2307/834332

Kumar, A. (Ed.). (2012). World bank literature. University of Minnesota Press.

Luis, S. K. (2019). Between anthropology and history: The entangled lives of Jangarh Singh Shyam and Jagdish Swaminathan. In S. Perera \& D. N. Pathak (Eds.), Intersections of contemporary art, anthropology and art history in South Asia (139-180). Palgrave.

Museum of London. (n.d.). Museum of London - Annual report 2004/05. www.museumoflondon.org.uk/application/files/9814/6796/7730/MOLAnnualReport200405.pdf

Perera, S., \& Pathak, D. N. (Eds.). (2019). Intersections of contemporary art, anthropology and art history in South Asia. Palgrave.

Prasad, A. (2015, September). Gondwana movement in post-colonial India: Exploring paradigms of assertion, self-determination and statehood. Journal of Tribal Intellectual Collective India 3(1): 37-45. http://www.ticijournals.org/gondwana-movement-in-post-colonial-india-exploring-paradigms-ofassertion-self-determination-and-statehood/

Ramanathan, R. (2014). Folk author: Collaborations between folk artist and publisher, a Tara Books case study. Journal of Illustration 1(1): 123-149. https://doi.org/10.1386/jill.1.1.123_1

Ray, B. (Ed.). (2005). Women of India: Colonial and postcolonial periods. PHISPC.

Shyam, B. (2004). The London jungle book. Tara Books.

Shyam, B., Urveti, R. S. \& Bai, D. (2006). The nightlife of trees. Tara Books.

Shyam, B. (2007). That's how I see things. Tara Books.

Tan, S. (2007). The arrival. Arthur A. Levine Books.

Vajpeyi, U. (2010). Jangarh kalam (T. Grover \& R. Singh, Trans.). Pratilipi (13). http://pratilipi.in/jangarhkalam-udayan-vajpeyi/

Verma, R. (2012). Developing fictions: The tribal in the new Indian writing in English. In A. Kumar (Ed.), World bank literature (216-233). University of Minnesota Press. 
Verma, R. (2013). Primitive accumulation: The political economy of indigenous art in postcolonial India.

Third Text 27(6): 748-761. https://doi.org/10.1080/o9528822.2013.857902

Wolf, G. (1997). Picturing words \& reading pictures: Illustrations and children's literature. Tara Publications.

Wolf, G. \& Arni, K. (Eds.). (2003). Beasts of India. Tara Publications.

Wolf, G. \& Rao, S. (2004). How London became a jungle. In B. Shyam, The London Jungle Book. Tara Books.

Wolf, G. \& Wolf, A. (Eds.). (2015). Between memory and museum: A dialogue with folk and tribal artists. Tara Books.

Shikha Singh is a PhD candidate at the Centre for English Studies, School of Language, Literature and Cultural Studies at Jawaharlal Nehru University, New Delhi, India. Her research interests include the South Asian visual culture, popular culture and media studies. 